\title{
Toward Green Supply Chain Management of Petrochemical Industry in Indonesia
}

\author{
Yuary Farradia, Abdul Talib Bon, Hendro Sasongko
}

\begin{abstract}
The Indonesia government put high effort on the integrated petrochemical industry development by strengthening research and development toward green industry of petrochemical industry in order to create more market potential as well as to achieve the sustainability. The green industry standard is closely related to raw materials, supported materials, energy, production process, product, company or manufacture management and waste management. Green Supply Chain Management (GSCM) concept involves the integration of environmentally conscious thinking into all phases of key supply chain management processes. Such activities include green materials sourcing, design of products with consideration given to their environmental impact based on packaging, purchasing, shipment and end of life management for products including easy recycling and or clean disposal. An effort toward GSCM has started being implemented by Petrochemical Producers in Indonesia.
\end{abstract}

Index Terms: Green Supply Chain Management, Green Industry, Sustainability, Petrochemical.

\section{INTRODUCTION}

The Asian region has been the chief driver of growth in the chemical industry in the last 25 years with nearly 50 percent of global sales already taking place in the region [1]. Its production capacities are expanding due to the high interlink ages in the economy, with chemical products serving as inputs to other industries. The upstream chemical industry is the most important in the value chain as it provides all the synthetic materials needed for further processing and it has been known that the upstream chemical industry is the petrochemical industry.

Petrochemical industry in Indonesia is one of the most important primary industries toward economic growth. The petrochemical industry is the sector experiencing the highest growth in Indonesia, and its demand has growing by approximately $2 \%$ per year [2]. This is correlated with the economic expansion of Indonesia, since petrochemical derivative products are utilized in the production process of plastic products, pharmaceuticals and textiles, amongst others.

Indonesia Investment Coordinating Board, (2011) stated that Petrochemical industry based on the production process as well as its product output characteristics / production basis

Revised Manuscript Received on April 25, 2019.

Yuary Farradia, Faculty of Technology Management and Business, Universiti Tun Hussein Onn Malaysia, Batu Pahat, Malaysia.

Abdul Talib Bon, Faculty of Technology Management and Business, Universiti Tun Hussein Onn Malaysia, Batu Pahat, Malaysia.

Hendro Sasongko, Faculty of Economics, Pakuan University Bogor, Indonesia. (horizontal basis), is also divided by three (3) group namely: 1. Methane (C1) in which producing ammonia, methanol, urea, formaldehyde, acetate acid, etc. ; 2. Olefin in which producing ethylene, propylene, butane, butylene, ethylene, glycol, polyethylene, etc.; 3. Aromatic in which producing benzene, Para xylene, Ortho xylene, toluene, Alkyl benzene, ethyl benzene, etc. In line with this petrochemical production process grouping then the ministry of Industry in Indonesia has established petrochemical cluster development subject to their road map. Therefore there are three cluster based on the region / province, such as Banten province for the Olefin basis, Kalimantan province as the basis for the Methane basis (C1) and East Java province for the aromatic basis. The Indonesia government put high effort on the integrated petrochemical industry development by strengthening research and development toward green industry of petrochemical industry in order to create more market potential as well as to achieve the sustainability [3]. One of the main problem faced in national industrial development was green industry standard in line with the energy scarcity due to high demand on the energy within the industry sector [4]. Some popular programs developed for ease of use environmentally conscious practices are started from design for environment, life cycle analysis, total quality environmental management, ISO 14001, up to an establishment of a Green Supply Chain Management (GSCM) concept.

Khaksar et al. (2015) study in petrochemical industry, determined important GSCM drivers as: internal environmental management, environmental regulations, green purchasing, cleaner production, recovery, eco-design and pollution, reverse logistic, green supplier, cooperation with customers, return investment and green innovation [5]. GSCM and Sustainable Supply Chain Management (SSCM) concepts ensure that environmental activities are applied by all departments in the industry [6]-[7]. By applying reverse logistics practices, industries can efficiently use the resources and prevent from pollution [8]. Because of great advantages, GSCM concept has attracted attention among practitioners and researchers in recent years [9]-[11].

Transition from traditional supply chain management to GSCM is influenced by many factors, known as pressures, and industries are adopting GSCM practices based on these indirect motivations (pressures) from different directions. 


\section{Toward Green Supply Chain Management an Overview of Petrochemical Industry in Indonesia}

\section{GREEN SUPPLY CHAIN MANAGEMENT PRACTICE}

A green supply chain is a new concept appearing in recent literatures. The practice of GSCM is getting popularity among operations managers especially with those who are pursuing the environmental performance of their operation [12]. Govindan et al., (2015) identified GSCM practices that consist of reverse logistics, product recovery and reuse of used products, green design, green purchasing, and collaboration with suppliers and customers. This is supported by Tseng, et al. (2015) who mentioned interrelationships among suppliers to reduce hazardous materials [13]. Hence, Green Supply Chain Management (GSCM) has emerged as a key approach for enterpriser seeking to make their businesses environmentally sustainable [14]. The integration of economic, environmental and social facets has been at the forethought of sustainability in today's operations management due to the successful implementation of green supply chain which eventually has led to overall sustainability of firms.

Khaksar, et al., (2015) study on testing the identification of main effecting factors on GSCM has concluded that there were eight activities placed in five levels. Internal Environment Management (IEM) and reverse logistic was ranked in the first level which this variable was a key factor, affecting eight other variables. In the other words it affects the applicability of eight other activities effectively. At the second level green supplier and green purchase, third level green designing and cooperation with the customers, level four return investment and finally green innovation ranked fifth. However, the calculated priority in this Khaksar, et al., (2015) study was not absolute and it was recommended to test these effecting factors of petrochemical industry at other countries.

The resource-based view (RBV) was developed by Wernerfelt (1984) who perceived a firm as a broader set of resources compared to the traditional view which accounts only for categories such as labour, capital and land [15]. Earlier study by Hart (1995) extended the RBV and included the natural environment as a previously ignored but important source of resources and capabilities, creating the Natural Resource Based View (NRBV) [16]. The NRBV then has often been used to study green practices in the supply chain [17]-[18]. Thus, GSCM practices are considered capabilities developed from a given set of firm resources [19].

Eco-Design refers to environmental design of a product and /or a process. It focuses on reducing (preventing) the environmental effects of a product before it is produced, distributed and used. Ecodesign is an approach to product design that makes special consideration of the environmental impact of the product during its entire life cycle.

Internal Environmental Management includes top management commitment, cross functional cooperation for environmental improvements, total quality environmental management, environmental compliance, environmental management system and ISO14001certification [20]-[21].

Green Purchasing refers to the procurement of products and services that have a reduced effect on human health and the environment when compared with competing products or services that serve the same purpose [22].

The Final stage in GSCM practices and functions is reverse logistics. As GSCM not only focuses on environmental issues but also economic aspects too, thus an appropriate reverse logistic system should be designed to achieve efficiency and thereby, achieve economic benefit for the company. The primary objective of reverse logistics is to maximize the activities taking place after selling the product such as customer service, warehousing and inspecting the quality which can act as another source of income, increase the satisfaction of the client as well as conserve the environment [23].

\section{DATA COLLECTION}

This study is an overview about GSCM practice at Petrochemical Industry in Indonesia. GSCM topic is still new in Indonesia, thus an exploratory and analytical approach in order deeply investigate the extent of GSCM practice in petrochemical industry in Indonesia. Given the nature and the objectives of this study, a qualitative method was preferred where data is collected using a semi-structured interviews. The use of interviews has been suggested for exploratory research when little is known about the phenomenon of interest (Sekaran\&Bougie, 2010) [24]. In addition, some data also taken from secondary sources that included published work in peer reviewed academic journals, high impact business magazines and reviews, media releases and websites, and documents obtained from the sample's officials.

According to Morse (1991), this type of qualitative research is needed because the topic is new and the subject has never been addressed with a certain sample or group of people, and existing theories do not apply with the particular sample or group under study [25].

The interview is conducted with eight representative respondents at manager level within the petrochemical industry particularly olefin based. Creswell (2014) stated that number of respondents required for phenomenology research is typically range from three to ten [26]. 20 open-ended questions as preliminary investigation (listed in the Appendix) are repeatedly asked and directed to the eight targets. The interviews have been performed at each company's location. Each interview lasted for about 20 minutes. The result of interview then was compiled. Table 1 presented the list of interviewees and fields of their business.

Table 1: List of Interviewees and Fields of the Business

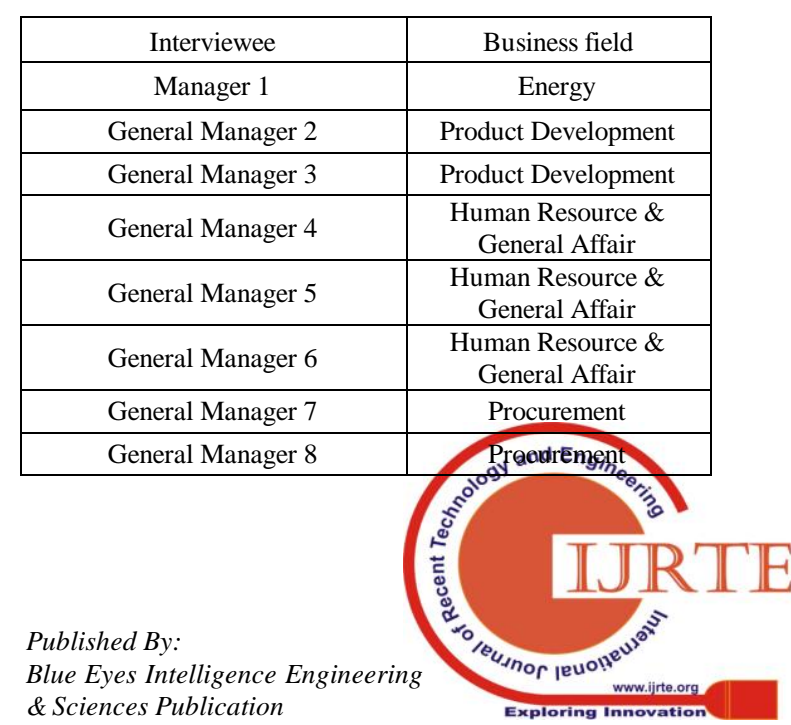




\section{GSCM PRACTICES IN INDONESIA}

This section is a brief explanation and interpretations regarding the GSCM practices at petrochemical in Indonesia based on preliminary investigation result.

Green industry standardization has started be implemented by some of the Petrochemical Producers. The green industry concept is in line with the effort of driving the organizations to focus on driving excellence through all areas of the organization from supply chain to operations, to channel management to sales and marketing, $\mathrm{R} \& \mathrm{D}$ and finance, toward firm sustainability. An environment policy has been issued by the Government is stated on the government regulation number 14 in year 2015 about national industry development main plan for 2015 - 2035 . One of these national industry development main plans for the period 2015 - 2035 is to improve the awareness of environment toward sustainability of industrial sector in future, development of green industry through new regulation on eco product, renewable energy and green environment as well as dangerous products.

Based on the Indonesia's Industry Ministry law no 51/M-Ind/PER/6/2015 about Green Industry Standard Arrangement Guidance, it was the aim to establish Green Industry within Indonesia based on particular green industry standard covering scope, definition, technical requirement as well as manufacturing process management. The Green Industry is an industry where in its production process put priority concern on both efficiency and effectively of their natural resources sustainability toward balancing the industrial development with sustainability of environment. The green industry standard (Standard Industry Hijab / SIH) is closely relate to raw materials, supported materials, energy, production process, product, company / manufacture management, waste management, etc. which aimed to establish the green industry. Implementation of a GSCM program is part of green industry strategy, such as efficiently utilization of national resource toward sustainability by implementing main concept of reduces, reuse, and recycle known as reverse logistic of the GSCM concept.

In line with the green industry program thus the Industrial Ministry of Indonesia have awarded Green Certificate to some petrochemical producers in 2017 as stated in Table 2. PT Chandra Asri Petrochemical has ecolabel certification issued by the Ministry of Environment for Developing Degradable plastic [27].

Table 2:Petrochemical Companies with Green

\begin{tabular}{|c|c|c|}
\hline Company Name & Group of Petrochemical & Green Level \\
\hline $\begin{array}{c}\text { BP Petrochemicals } \\
\text { Indonesia }\end{array}$ & Olefin Based & Level 5 \\
\hline $\begin{array}{c}\text { Chandra Asri } \\
\text { Petrochemical Tbk }\end{array}$ & Olefin Based & Level 5 \\
\hline $\begin{array}{c}\text { Dow Agrosciences } \\
\text { Indonesia }\end{array}$ & Olefin Based & Level 5 \\
\hline Ecogreen Oleochemicals & Olefin Based & Level 4 \\
\hline Nippon Shokubai & Olefin Based & Level 5 \\
\hline Petrokimia Gresik & Methane (C1) Based & Level 5 \\
\hline
\end{tabular}

In addition, most of Indonesia petrochemical producers have been certified by various green related certificates as stated in Table 3.
Table 3. Green Related Certificate and Award

\begin{tabular}{|c|c|c|c|}
\hline Company Name & Certificate/ Award & Certificate & Local Award \\
\hline $\begin{array}{c}\text { BP } \\
\text { Petrochemicals } \\
\text { Indonesia }\end{array}$ & $\begin{array}{c}\text { ISO } 14001: 2004 \\
\text { ISO } 14001: 2005\end{array}$ & $\begin{array}{c}\mathrm{V}^{* *} \\
\mathrm{~V}^{*}\end{array}$ & \\
\hline $\begin{array}{c}\text { Chandra Asri } \\
\text { Petrochemical } \\
\text { Tbk }\end{array}$ & $\begin{array}{c}\text { ISO } 50001: 2011 \\
\text { ENVIRONMENTAL }\end{array}$ & $\mathrm{V}^{* *}$ & $\mathrm{~V}$ \\
\hline $\begin{array}{c}\text { Dow } \\
\text { Agrosciences } \\
\text { Indonesia }\end{array}$ & $\begin{array}{c}\text { PROPER } \\
\text { PROPERDA }\end{array}$ & $\mathrm{V}^{*}$ & $\mathrm{~V}$ \\
\hline $\begin{array}{c}\text { Ecogreen } \\
\text { Oleochemicals }\end{array}$ & $\begin{array}{c}\text { ECOLABEL } \\
\text { ECO-FRIENDLY }\end{array}$ & $\mathrm{V}^{*}$ & $\mathrm{~V}$ \\
\hline Nippon Shokubai & HALAL & $\mathrm{V}^{*}$ & \\
\hline Petrokimia Gresik & $\begin{array}{c}\text { GREEN INDUSTRY } \\
\text { GREEN STAR }\end{array}$ & $\mathrm{V}^{* *}$ & $\mathrm{~V}$ \\
\hline
\end{tabular}

*: Local **: International

The interview summary presented in table 4 up to table 6 .

Table 4. Internal GSCM Implementation

\begin{tabular}{|c|c|c|}
\hline Respondent Position & Eco-Design & $\begin{array}{c}\text { Internal } \\
\text { Environmental } \\
\text { Management }\end{array}$ \\
\hline Energy Manager & $\begin{array}{c}\text { High extent level on } \\
\text { product design with } \\
\text { minimum energy usage }\end{array}$ & $\begin{array}{c}\text { High extent level on the } \\
\text { Environment } \\
\text { Management policy } \\
\text { awareness }\end{array}$ \\
\hline $\begin{array}{c}\text { Product Development } \\
\text { General Managers }\end{array}$ & $\begin{array}{c}\text { Very high extent level } \\
\text { on product design with } \\
\text { minimum level of waste }\end{array}$ & $\begin{array}{c}\text { Very high extent level } \\
\text { on the environment } \\
\text { management policy } \\
\text { awareness }\end{array}$ \\
\hline $\begin{array}{c}\text { HR-GA General } \\
\text { Managers }\end{array}$ & $\begin{array}{c}\text { Very high extent level } \\
\text { on product design with } \\
\text { minimum level of waste }\end{array}$ & $\begin{array}{c}\text { Very high extent level } \\
\text { on the environment } \\
\text { management policy } \\
\text { awareness }\end{array}$ \\
\hline $\begin{array}{c}\text { Procurement General } \\
\text { Managers }\end{array}$ & $\begin{array}{c}\text { Very high extent level } \\
\text { on product design with } \\
\text { minimum level of waste }\end{array}$ & $\begin{array}{c}\text { Very high extent level } \\
\text { on the environment } \\
\text { management policy } \\
\text { awareness }\end{array}$ \\
\hline
\end{tabular}

Table 5. External GSCM Implementation

\begin{tabular}{|c|l|l|}
\hline Respondent Position & \multicolumn{1}{|c|}{ Green Purchasing } & \multicolumn{1}{c|}{ Reverse Logistic } \\
\hline $\begin{array}{c}\text { Energy } \\
\text { Manager }\end{array}$ & $\begin{array}{l}\text { High extent level on } \\
\text { product specification } \\
\text { standard subject to the } \\
\text { environment } \\
\text { consideration }\end{array}$ & $\begin{array}{l}\text { High extent level on the } \\
\text { effort of reduce, } \\
\text { reuse and recycle } \\
\text { products toward cost } \\
\text { saving purpose. }\end{array}$ \\
\hline \multirow{5}{*}{$\begin{array}{c}\text { Product Development } \\
\text { General Managers }\end{array}$} & $\begin{array}{l}\text { Very high extent level } \\
\text { on product specification } \\
\text { standard subject to the } \\
\text { environment } \\
\text { consideration }\end{array}$ & $\begin{array}{l}\text { Very high extent level } \\
\text { on the effort of reduce, } \\
\text { reuse and recycle } \\
\text { products toward cost } \\
\text { saving purpose. }\end{array}$ \\
\hline HR-GA & $\begin{array}{l}\text { Very high extent level } \\
\text { on product specification } \\
\text { standard subject to the } \\
\text { environment } \\
\text { consideration }\end{array}$ & $\begin{array}{l}\text { Very high extent level } \\
\text { on the effort of reduces, } \\
\text { reuse and recycle } \\
\text { products toward cost } \\
\text { saving purpose. }\end{array}$ \\
\hline Procurement General \\
Managers
\end{tabular}


Table 6:Reason for GSCM Initiatives

\begin{tabular}{|c|c|}
\hline GSCM & Reason \\
\hline Eco Design & $\begin{array}{l}\text { 1. Product design subject to } \\
\text { government environment } \\
\text { regulation. } \\
\text { 2. Production process concepts refer } \\
\text { to waste minimization target. } \\
\text { 3. Raw materials are designed to be } \\
\text { able for either be recycled or } \\
\text { reused. } \\
\text { 4. Energy is minimized by coal } \\
\text { utilization as one of the energy } \\
\text { alternative. }\end{array}$ \\
\hline $\begin{array}{c}\text { Internal } \\
\text { Environment } \\
\text { Management }\end{array}$ & $\begin{array}{l}\text { 1. There is company environment } \\
\text { policies enforcement to the } \\
\text { employee. } \\
\text { 2. Some environment activities } \\
\text { implemented by the employee such } \\
\text { as cleaning day, green program of } \\
\text { corporate social responsibility to } \\
\text { the surrounding community, } \\
\text { implementation of } 5 \mathrm{~S} \text { best practice } \\
\text { (Seiri,Seiton, Seiso,Seiketsu, } \\
\text { Shitsuke) up to } 1000 \text { trees plant } \\
\text { program. }\end{array}$ \\
\hline Green Puchasing & $\begin{array}{l}\text { 1. Supplier / Vendor selection is based } \\
\text { on ISO } 14001 \text { standardization. } \\
\text { 2. Always cooperate with supplier / } \\
\text { vendor toward production } \\
\text { capacity development }\end{array}$ \\
\hline $\begin{array}{l}\text { Reverse } \\
\text { Logistics }\end{array}$ & $\begin{array}{l}\text { 1. Return products from clients are } \\
\text { expected be recycle, re-use and } \\
\text { down grade re-production. } \\
\text { 2. Handling return products from } \\
\text { client are due to cost saving reason. } \\
\text { 3. There are dedicated clients for ex } \\
\text { return products. }\end{array}$ \\
\hline
\end{tabular}

\section{KEY DRIVER FOR GSCM INITIATIVE}

In Country perspective, the Environment Management in Indonesia was managed by the Ministry of Environment and Forestry (MOEF). The Ministry of the Environment and Forestry (MOEF) is the primary administrator of environmental law in Indonesia, which is principally regulated by Law No. 32 on Environmental Management and Protection. PROPER is one of government program to review and give rating on the corporation subject to environmental management system standardization. PROPER was designed to improve better environmental management implemented by the corporation based on incentive and disincentive reward. The incentive is given by a label reward of Blue, Green and Gold. Whilst the nonperform label is red and black.

The assessment covers aspects related to documentation, environmental permits, water and air pollution control, hazardous waste management, and the monitoring of environmental parameters according to prevailing regulations. The program has been studied and emulated around the world. Other environmental Management System implemented in Indonesia is ISO 14001 for the quality system, Energy, water and waste management. Another environment policy issued by the Government is stated on the government regulation number 14 in year 2015 about national industry development main plan for 2015 2035. One of these national industry development main plans for the period $2015-2035$ is to improve the awareness of environment toward sustainability of industrial sector in future, development of green industry through new regulation on eco product, renewable energy and green environment as well as dangerous products.

Eco Friendly Product certification is the latest development for having Eco label issued by Indonesia Ministry of Environment for developing degradable plastic, green. Green degradable plastic resins are designed to be 'fit for purpose'; they achieve their functional competency prior to degradation after disposal. It takes approximately 2 years to completely degrade whereas a conventional plastic takes 1000 years to degrade.

\section{DISCUSSION}

The green industry concept is in line with the effort of driving the organizations to focus on driving excellence through all areas of the organization from supply chain to operations, to channel management to sales and marketing, R\&D and finance, toward firm sustainability. Though the understanding of GSCM practices still new for the industry however in fact, it has been implementing within petrochemical industry in Indonesia in particular at olefin based industry. This paper explains various aspects of GSCM. Based on this paper we understand the importance of implementation of GSCM in industries from environmental protection point of view. Therefore, government and top level management should take initiatives to practice GSCM successfully and help nation to save and preserve environment.

\section{CONCLUSION}

These overviews of green supply chain management practices at petrochemical industry in Indonesia revealed that majority of the producers have started to implement the GSCM practices. On the other hand, review of literature also confirmed that the GSCM practice is strongly recommended in line with the national vision toward green industry long run objective.

\section{APPENDIX}

\begin{tabular}{|c|l|}
\multicolumn{1}{|c|}{ Questions of the interviews } \\
\hline No & \multicolumn{1}{c|}{ Question } \\
\hline 1 & $\begin{array}{l}\text { What is your position in the managerial structure (GM, Manager, } \\
\text { Assistant Manager)? }\end{array}$ \\
\hline 2 & Are GSCM concepts applied in your company framework? \\
\hline 3 & $\begin{array}{l}\text { What is your position in Supply Chain: Procurement? Production? } \\
\text { Human Resource? Product Development? Maintenance? }\end{array}$ \\
\hline 4 & $\begin{array}{l}\text { To what extent level is the product design implementation subject } \\
\text { to energy minimization? }\end{array}$ \\
\hline 5 & $\begin{array}{l}\text { To what extent level is the product design implementation subject to } \\
\text { waste minimization? }\end{array}$ \\
\hline 6 & $\begin{array}{l}\text { To what extent level is the environment management policy } \\
\text { implementation subject to environment consideration? }\end{array}$ \\
\hline 7 & $\begin{array}{l}\text { To what extent level is the product specification standard subject to } \\
\text { the environment consideration? }\end{array}$ \\
\hline 8 & $\begin{array}{l}\text { To what extent level is the effort of reduce, reuse and recycle } \\
\text { products toward cost saving purpose? }\end{array}$ \\
\hline 9 & How does company make the product design? \\
\hline 10 & What is the production concept refer to he wastenginimization? \\
\hline 11 & What is the concept of raw material seloction? \\
\hline 12 & What is one of the effort in order to ninimize the energy usage? \\
& $\begin{array}{l}\text { Published By: } \\
\text { \& Sciences Publication }\end{array}$ \\
\hline 4
\end{tabular}




\begin{tabular}{|l|l|}
\hline 13 & Is there any company regulation on environment policy? \\
\hline 14 & State an example of environment policy implemented to all staff \\
\hline 15 & How is the policy of supplier selection? \\
\hline 16 & How is the relationship policy with the supplier? \\
\hline 17 & Is there any policy to handle return product from customer? \\
\hline 18 & What is the policy in handling return product ? \\
\hline 19 & $\begin{array}{l}\text { What is the relationship between return product with cost } \\
\text { management? }\end{array}$ \\
\hline 20 & Are there any third party as buyer for ex return product? \\
\hline
\end{tabular}

\section{ACKNOWLEDGMENT}

Many thanks for the Petrochemical Producers Olefin based in Banten province for their information contribution on both secondary data and primary data.

\section{REFERENCES}

1. S. Evans, S. Fokeer and G. Rezonja. Sustainable assessment of chemical industries for policy advice. The case of The Philippines, Thailand, Indonesia and Vietnam. London: Research, Statistics and Industrial Policy, 2015.

2. C. Suwanna.. Economic Intelligence Centre, Petrochemical Business in Indonesia, 2014.

3. Ministry of the State Secretariat. Indonesia Development Regulation, 2015.

4. Ministry of Industry. Indonesia's Industry Report, 2015.

5. E. Khaksar, R. A. Kahanaali, A. Tizroo and F. B. Rad. "An analysis of the effective actions on green supply chain management using ISM method (Studying the petrochemical industry)." Journal Material Environment. Science. vol. 6, no. 7, pp. 1987-1996, 2015.

6. K. Govindan, S. Rajendran, J. Sarkis and P. Murugesan. "Multi criteria decision making approaches for green supplier evaluation and selection: a Literature review." Journal of Cleaner Production, vol 98, pp. 66-83, 2015 .

7. K. Mathiyazhagan, A. Diabat, A. Al-Refaie and L. Xu. "Application of analytical hierarchy process to evaluate pressures to implement green supply chain management." Journal of Cleaner Production, vol. 107, pp. 229-236, 2015.

8. C. Prakash and M. K. Barua. "Integration of AHP-TOPSIS method for prioritizing the solutions of reverse logistics adoption to overcome its barriers under fuzzy environment." Journal of Manufacturing Systems. vol. 37, pp. 599-615, 2015.

9. K. Muduli, A. Barve, D. Kannan and Y. Geng. "Role of behavioural factors in green supply chain management implementation in Indian mining industries." Resources Conservation and Recycling, vol. 76, pp. 50-60, 2013

10. T. Abdallah, A. Diabat and J. Rigter. "Investigating the option of installing small scale PVs on facility rooftops in a green supply chain.' International Journal of Production Economics, vol. 146, no. 2, pp. 465-477, 2013

11. L. Xu, K. Mathiyazhagan, K. Govindan, A. N. Haq, N. V. Ramachandran and A. A. kumar. "Multiple comparative studies of green supply chain management: pressures analysis." Resources, Conservation and Recycling, vol. 78, pp. 26-35, 2013.

12. S. Islam, N. Karia, F. B. A. Fauzi and M. S. M. Soliman, "A review on green supply chain aspects and practices", Management and Marketing. Challenges for the Knowledge Society, vol. 12, no. 1, pp. 12-36, 2017.

13. M. L. Tseng, K. Tan and A. S. Chiu, "Identifying the competitive determinants of firms' green supply chain capabilities under uncertainty", Clean Technologies and Environmental Policy, vol. 18, no. 5, pp. 1-16, 2015.

14. N. Moharamned, M. Aghajani, F. Atabi and Azarkamand "Petrochemical Supply Chain's Share in Emission of Green House Gases, Case Study: Shazand Petrochemical Complex." American Journal of Environmental Science, vol. 9, no. 4, pp. 334-342, 2013.

15. Wernerfelt, B. (1984) A resource-based view of the firm. Strategic Management Journal, Vol. 5 (2), 171-180.

16. S. L. Hart. "A natural-resource-based view of the firm." The Academy of Management Review, vol. 20, no. 4, pp. 986-1014, 1995.

17. S. Vachon and R. D. Klassen. "Environmental management and manufacturing performance: The role of collaboration in the supply chain.” International Journal of Production Economics, vol. 111, no. 2, pp. 299-315, 2008.

18. S. Vachon and R. D. Klassen. "Extending Green Practices Across The Supply Chain: The Impact of Upstream and Downstream Integration."
International Journal of Operations \& Production Management, vol. 26, no. 7, pp. 795-821, 2006.

19. S. L. Golicic and C. D. Smith. "A meta-analysis of environmentally sustainable supply chain management practices and firm performance." Journal of Supply Chain Management, vol. 49, no. 2, pp. 78-95, 2013.

20. S. Bag, N. Anand and K. K. Pandey. Green supply chain management model for sustainable manufacaturing practices. In Green supply chain management for sustainable business practice. Pennsylvania: IGI Global, 2017.

21. M. D. Guerrero-Baena, J. A. Gomez-Limon, J. F. Fruet. "A multi-criteria method for environmental management system selection: an intellectual capital approach.” Journal Clean Production, vol. 105, pp. 428-437, 2015.

22. M.S Vishal, and S. Avinash. "Green Supply Chain Management - An Overview". International Journal of Advanced Engineering and Innovative Technology (IJAEIT) ISSN No 2348-7208. Special Issue on "Emerging Technology for Innovative India", vol 3. issue 1. 2016

23. M. Christopher. Logistics \& supply chain management. UK: Pearson Publisher, 2016.

24. U.Sekaran and R. Bougie. Research Methods for Business: A skill Building Approach. Uk: John Willey \& Son.2010

25. J. M. Morse. "Approaches to qualitative-quantitative methodological triangulation." Nursing Research, vol. 40, no. 1, pp. 120-123, 1991.

26. J. W. Creswell. Research Design: Qualitative, Quantitative, and Mixed Methods Approaches. United States: Sage Publisher, 2014

27. Chandra Asri Annual Report (2016 - 2017). PT Chandra Asri Petrochemical Tbk., Indonesia. 